\title{
Gender and the Sustainable Development Goals
}

\section{Karen Morrow}

\section{Abstract}

This chapter considers key factors shaping the pursuit of gender equality and women's empowerment under the SDGs. In so doing, it examines some of the most significant concerns that may militate against the goals achieving these ends. These include, the legacy of the MDGs regime and in particular the limitations that have become apparent during its operation in progressing societal change through the goals, targets, and indicators, oriented approach pioneered therein and pursued in the successor SDG regime. The chapter also discusses the tensions inherent in the adoption of a discrete gender goal on the one hand and integration of gender under other goals on the other. The principal advantage of a discrete gender goal lies in according 'headline' status to the issue; integration in other goals however offers the potential to 'mainstream' gender coverage key substantive areas. The concomitant disadvantages of these approaches are potentially 'siloing' gender issues and dilution of focus respectively. The use of indicators and their limitations, particularly in light of current levels of information and communications technology and data challenges are interrogated. The chapter concludes by examining the implications of the international community's broader evasion of the interface between goals regimes and the global human rights agenda for gender issues. Discussion centres around the fact that, as gender concerns now enjoy strong coverage in human rights law along with the legal status that this invokes, divorcing the SDGs regime from such protection stands to act to the particular disadvantage of women, negating a key route to securing accountability for the impacts of state action/inaction on the ground. 


\section{Introduction: Goals, Rights and Gender}

This chapter examines the coverage offered by the Sustainable Development Goals (SDGs) ${ }^{1}$

to gender issues. ${ }^{2}$ It considers the legacy of the Millennium Development Goals (MDGs) ${ }^{3}$ and the signal importance of the continuing reluctance of states to give substantive cognisance to links between development goals and human rights thus ensuring that they remain confined to the political rather than the legal realm. While this approach permeates the goals, this chapter will argue that, for gender issues, with their hard-won but now established human rights-based characterisation, the mismatch is particularly acute, and the potential salience of the goals to the gender constituency is greatly compromised as a result.

\section{Gender and the UN - a brief primer}

The United Nations (UN) has been formally committed to human equality generally, and gender equality specifically, since its inception, rejecting distinction/discrimination on grounds of sex in the Charter of the United Nations in $1945,{ }^{4}$ and the Universal Declaration of

\footnotetext{
${ }^{1}$ UNDP Sustainable Development Goals <http://www.undp.org/content/undp/en/home/sustainable-developmentgoals.html> accessed 15 May 2017.

${ }^{2}$ Discussion of gender is prominent in A/Res/70/1 Transforming our world: the 2030 Agenda for Sustainable Development 21 October 2015 (Agenda 2030) <http://www.un.org/ga/search/view_doc.asp?symbol=A/RES/70/1\&referer=/english/\&Lang=E> accessed 10 July 2017, which features 32 references to 'women/women and girls' across a 35 page document. Notably though, while the 1995 Beijing Platform for action is listed among the UN documents that have '... laid a solid foundation for sustainable development and ... helped to shape the new Agenda.' (para 11), other key documents relating to gender, such as the Convention on the Elimination of All Forms of Discrimination Against Women 1979 are not.

3 Millennium Development Project, Millennium Development Goals

<http://www.unmillenniumproject.org/goals/> accessed 29 July 2016.

${ }^{4}$ The preamble of which affirmed the 'equal rights of men and women' and Article 8 committing the UN to proceeding on the basis of unrestricted 'eligibility of men and women to participate in any capacity and under conditions of equality in-its principal and subsidiary organs'. Charter of the United Nations <https://treaties.un.org/doc/publication/ctc/uncharter.pdf> accessed 29 July 2016.
} 
Human Rights $1948 .{ }^{5}$ Women's concerns also gained fairly early specific coverage in the Convention on the Political Rights of Women $1952,{ }^{6}$ though it can be argued that this type of approach is not an unalloyed good as it can serve to reduce gender concerns to 'women's issues', rather than seeking to address the deep embedded structural inequality that lies at their root. ${ }^{7}$ The focus on gender equality in the UN's mainstream human rights instruments was reiterated in the common Article 3 provisions of the International Covenant on Civil and Political Rights $1966^{8}$ and the International Covenant on Economic, Social and Cultural Rights $1966,{ }^{9}$ which refer to the 'equal right of men and women' to the enjoyment of their respective provision.

The existence of law does not of course alone ensure its efficacy, to the extent that it has been argued, with some force, that: '... women's historic hold on human rights has been both ambiguous and tenuous. ${ }^{10}$ It is certainly the case that the UN's gender agenda took some considerable time to even begin to mature, and it was in the end a women-focussed approach that seeded this development, with International Women's Year 1975 and the UN Decade for Women (1976-1985) and their supporting conferences providing the impetus for the Convention on the Elimination of All Forms of Discrimination Against Women 1979

\footnotetext{
${ }^{5}$ General Assembly Resolution 217 (III) A, 10 December 1948, the preamble of which refers to the "equal rights of men and women' http://www.ohchr.org/EN/UDHR/Documents/UDHR_Translations/eng.pdf accessed 29 July 2016.

${ }^{6}$ General Assembly resolution 640(VII) online at <https://documents-ddsny.un.org/doc/RESOLUTION/GEN/NR0/079/83/IMG/NR007983.pdf?OpenElement> accessed 29 July 2016. 7 S. Arora-Jonsson, 'Forty Years of Gender Research and Environmental Policy: Where Do We Stand?' (2014) 47 Women's Studies International Forum 47, 295.

${ }^{8}$ General Assembly Resolution 2200A (XXI) of 16 December 1966 online at <http://www.ohchr.org/en/professionalinterest/pages/ccpr.aspx > accessed 07 December 2016.

${ }^{9}$ General Assembly Resolution 2200A (XXI) of 16 December 1966 online at <http://www.ohchr.org/EN/ProfessionalInterest/Pages/CESCR.aspx> accessed 07 December 2016.

${ }^{10}$ M. Pardy, 'Under Western Eyes Again? Rights Vernacular and the Gender Culture 'Clash' (2013) 19(1) Australian Journal of Human Rights 19(1), 39.
} 
(CEDAW), ${ }^{11}$ finally setting gender on a sound foundation within the organisation and numerous subsequent institutional developments securing the place of and at the same time giving new prominence to women's issues on the international stage. ${ }^{12}$

Acceptance in principle was however slow to generate headway in practice, as highlighted by the Beijing Declaration and Programme for Action $1995,{ }^{13}$ and the UN was ultimately forced to change tack in the search for efficacy, developing the concept of gender mainstreaming in the attempt to translate commitments on paper to progress in the real world. ${ }^{14}$ While gender mainstreaming has not by any means proven a global panacea for the ills of gender inequality (arguably merely 'bureaucratizing the idea of gender'15), it has, in conjunction with other developments, such as the emergence of innovative international governance in the context of sustainable development (under the rubric of the "social pillar"), ensured that gender is now at least (for the most part) both firmly present on the agenda and institutionalised in many of the UN's activities.

The several developments at UN level outlined above, while indicating a degree of progress at an organisational level, tend to mask the fact that gender equality remains a matter of profound disagreement and dispute among states. ${ }^{16}$ This was very evident throughout the

\footnotetext{
${ }^{11}$ UN Women Convention on the Elimination of All forms of Discrimination Against Women <http://www.un.org/womenwatch/daw/cedaw/text/econvention.htm> accessed 29 July 2016.

${ }^{12}$ Discussed in Karen Morrow, Not so Much a Meeting of Minds as a Coincidence of Means: Ecofeminism, Gender Mainstreaming and the UN' (2006) Thomas Jefferson law Journal 28(2) 185.

${ }^{13}$ UN Women Beijing Declaration and Platform for Action <http://www.unwomen.org/ /media/headquarters/attachments/sections/csw/pfa_e_final_web.pdf > (accessed 29 July 2016).

14 Morrow, above n 12.

15 Arora-Jonsson, above n 7, 303.

${ }^{16}$ Notable laggards on women's rights include, the Holy See, and many Islamic States, see with reference to the SDG process S. Gabizon, et al, Sustainable Development Goals and the 2030 Agenda, Women's Major Group at UNEP, UNEP, Perspectives, Issue no. 17, October 2015, <https://wedocs.unep.org/rest/bitstreams/10863/retrieve> accessed 12 May 2017; and, more broadly Z. F. K.
} 
formation of the SDGs, which exhibited constant pressure on some fronts to remove or play down references to gender in them. ${ }^{17}$ In the end though, thanks in part to constant, coordinated and high profile work by civil society, ${ }^{18}$ the current (though by no means unthreatened $)^{19}$ globally prevailing recognition of gender equality won out, and gender was accorded both discrete 'headline' coverage in SDG 5 (achieve gender equality and empower all women and girls) and was recognised as raising clear implications in respect to many of the others. Gender is also a recurrent feature in the regime's supporting targets.

It is also worth reflecting not only on the institutional, but also the wider (if not universal) societal, climate created by the UN's largely rights-based engagement with gender over the decades. The fundamental and embedded rights-based approach to gender has generated basic expectations on how gender issues are to be addressed, with women/gender activists and institutions employing rights-talk as an established foundation to exhort action across a wide variety of spheres; ${ }^{20}$ and many states, having signed up to (some or all of) the various agreements alluded to above, recognise (albeit to varying degrees) the force that such rights-based claims can invoke. As we shall see below, the goals-based approaches to development that have emerged first through the MDGs, and latterly the SDGs, have seen

\footnotetext{
Arat, 'Promoting Women's Rights against Patriarchal Culture Claims: The Women's Convention and Reservations by Muslim States' in David P. Forsythe and P. C. McMahon (eds), Human rights and Diversity: Area Studies Revisited (University of Nebraska Press 2003).

${ }^{17}$ Women's Major Group: "Women's "8 Red Flags"' Following the Conclusion of the Open Working Group on Sustainable Development Goals (SDGs)' 21 July 2014, (hereafter WMG: Women's “8 Red Flags'”) <http://www.wedo.org/wp-content/uploads/Womens-Major-Group_OWG_FINALSTATEMENT_21July.pdf> accessed 09 August 2016.

${ }^{18}$ Ibid, 1.

${ }^{19}$ See, for example, J. Squires: The New Politics of Gender Equality (Palgrave Macmillan 2007).

${ }^{20}$ See for example, Women and Gender Constituency: 'Gender Just Climate Solutions' Women Engage for a Common Future, Utrecht (2016) <http://www.wecf.eu/english/publications/2016/ENG-

WGCSolutionsPublFINALWEB.pdf> accessed 09 May 2017.
} 
real and fundamental tensions emerge between them and rights-based approaches more generally and with marked effect in respect of gender.

Given the comparatively well-primed UN approach to gender generally, it was on balance no surprise that it featured prominently among the MDGs, ${ }^{21}$ and we will consider the approach adopted therein in greater detail below, as it directly sets the scene for current developments. For now, it suffices to say that, while the MDGs delivered a degree of progress on their gender-oriented objectives on the ground, ${ }^{22}$ much remains to be done. Thus, as the shift towards gender equality remains very much work in progress, it will become apparent that gender necessarily retains a significant presence in the expanded successor regime.

A relatively short chapter cannot hope to offer full coverage of the myriad issues arising in respect of gender and international policy developments, but it can illustrate the direction of travel. To that end, the chapter will focus primarily on key factors shaping the pursuit of gender equality and women's empowerment under the SDGs (not least, the legacy of the MDGs) and some of the likely impediments to their full realisation, notably the limitations of indicators-based goals and the continuing failure of the international development goals regime to engage effectively with the human rights agenda. ${ }^{23}$

\section{The MDG's Legacy on Gender}

\footnotetext{
${ }^{21}$ MDGs, above n 3.

22 United Nations: The Millennium Development Goals Report 2015 (hereafter UN MDG Report 2015)

<http://www.un.org/millenniumgoals/2015_MDG_Report.pdf> accessed 18 November 2016 4-9.

${ }^{23}$ See also Lynda Collins' chapter in this volume.
} 
The question of how best to address gender concerns is, at best, a fraught one - and experience with the MDGs suggests that it is debatable whether it is in fact capable of a 'right' answer. The MDGs ultimately adopted a two-pronged approach: on the one hand including a specific gender goal and discrete targets; and on the other integrating gender considerations into other goals and their targets. In so-doing, it arguably sought to achieve the best of both worlds.

The inclusion of the gender-oriented MDG 3 was an important development in principle, according gender a degree of prominence commensurate with other core concerns within the regime such as eradicating poverty and hunger. At the same time, there was a downside to this, as embodying gender within a discrete goal created the conceptual danger of allowing it to be/become isolated as an issue by exposing it to the risk of being siloed at this level of the MDG regime. This tendency was however ostensibly offset by the second approach, ensuring that gender featured in targets falling under other goals, ${ }^{24}$ which created opportunities to integrate and mainstream gender within the broader MDG regime. That said, it can be argued that this approach too has its dangers, as treating gender as a cross-cutting issue can create the danger that it is subsumed in other concerns. ${ }^{25}$ Even if this was not demonstrably the case, the supporting role accorded to gender in this context arguably sent a significant signal as to its subsidiary status where it did appear. While it may have been hoped that the defects of one approach will serve to offset those of the other,

\footnotetext{
${ }^{24}$ Gender features to some degree in the targets for most of the other MDGs - Goal 1: Eradicate Extreme Poverty and Hunger - Target 1A; 1B; Goal 2: Achieve Universal Primary education - Target 2.A.; Goal 4: Reduce Child Mortality - Target 4A; Goal 5 Improve Maternal Health - Target 5A, 5B; Goal 6 Combat HIV/AIDS, malaria and other diseases - Target 6A (gender disaggregated data and gender differentiated impacts), and Goal 8 Develop a global partnership for development - Target 8A, $<$ http://www.un.org/millenniumgoals/> accessed 15 May 2017.

${ }^{25}$ E. Harrison, 'Bouncing Back? Recession, Resilience and Everyday Lives' (2012) Critical Social Policy 33(1) 97.
} 
this is not a given. In any event, ensuring that this would be the case would have required a very careful and coordinated eye to be given to goal and target design to this specific end at best unlikely in the context of a highly politicised internationally negotiated process which is inevitably characterised by powerplays and strategic trade-offs.

The approach to gender invoked by MDG 3, as with the other goals in this regime, focussed attention on the developing world, conveniently ignoring the fact that gender issues give cause for concern globally. Its supporting targets were concentrated on indicators highlighting selected aspects of education, employment, and political participation. ${ }^{26}$ While these are laudable in themselves, this approach also served to effectively narrow the focus on gender issues ${ }^{27}$ as in raising the profile of these specific issues, it arguably incentivised states to focus their efforts and scarce resources on activities that would 'count' for the purposes of the MDGs - at the expense of a broader approach to addressing gender concerns trained on deeper culture change.

That said, the key targets under MDG 3 do demonstrate progress, albeit to varying degrees. The target of eliminating gender disparity in primary education by 2005 was achieved by a majority of developing regions. Less progress was however made on the target to do likewise for secondary education and progress on a 2015 target for tertiary education was

\footnotetext{
26 'Target 4 . Eliminate gender disparity in primary and secondary education, preferably by 2005, and in all levels of education no later than 2015. Indicators 9 and 10, overseen by UNESCO, focussed on the ratio of girls to boys at all levels of education and the literacy of literate women to men aged 15-24; Indicator 11, overseen by the ILO, focussed on women in waged employment outside the agricultural sector; and Indicator 12 overseen by the IPU focussed on the proportion of women in national parliaments <http://www.un.org/millenniumgoals/> accessed 15 May 2017.

${ }^{27}$ See, for example, N. Kabeer, 'Gender Equality and Women's Empowerment: A Critical Analysis of the Third Millennium Development Goal' (2005) Gender and Development 13(1), 13.
} 
more limited still. ${ }^{28}$ In terms of women's access to paid employment - while opportunities for women have slowly increased, gender remains a source of disadvantage for women. ${ }^{29}$ Insofar as women's political representation is concerned, here again there has been progress (notably in seeing average representation increase from $11 \%$ in 1995 to $22 \%$ in 2015 and in developing regions ${ }^{30}$ increasingly exceeding that in the developed world). ${ }^{31}$ Despite these initially encouraging results, latterly it appears that progress on political representation has stalled..$^{32}$ Furthermore, the depth of change wrought is questionable and it is significant that women continue to be largely absent from leadership positions. These headlines also mask the fact that disparities in gender equality between developing regions remain at all levels, ${ }^{33}$ though this is also the case in the developed world. With this in mind, gender equality is one area where the SDGs in rolling out regime coverage to all states, will, albeit belatedly, place the performance of the latter too under justified scrutiny.

Progress under the 8 MDG goals and targets was ultimately expressed through 21 targets which were launched by the UN Secretary-General and made the subject of an annual report. ${ }^{34}$ These were fleshed out by and 60 MDG Indicators, ${ }^{35}$ which, to establish their credibility, were selected by and operated under the auspices of the Inter-Agency and

\footnotetext{
${ }^{28}$ UN MDG Report 2015, above n 22, 28.

${ }^{29}$ Ibid, 30.

${ }^{30}$ Ibid, 31.

${ }^{31}$ UNDP: The Path to Achieving the Millennium Development Goals: A Synthesis of Evidence from Around the World, (2010) (hereafter UNDP Path) <http://www.ghd-net.org/sites/default/files/2\%20UNDP_The\%20path\%20to\%20achieving\%20MDGs_0.pdf> accessed 20 October 2016, p 27.

32 This was observed in 2014, suggesting that the 'low hanging fruit' may now have been plucked and that further advancement may provide considerably more problematic - UN MDG Report 2015, above n 22 . .

${ }^{33}$ Ibid, 28-31.

${ }^{34}$ A/56/326, Road Map Towards the Implementation of the United Nations Millennium Declaration, 6 September 2001 <https://mdgs.un.org/unsd/mdg/Resources/Static/Products/SGReports/56_326/a_56_326e.pdf> accessed 09 May 2017.

${ }^{35}$ Millennium Development Goals indicators: Official list of MDG Indicators

<https://mdgs.un.org/unsd/mdg/Host.aspx?Content=Indicators/OfficialList.htm> accessed 17 May 2017.
} 
Expert Group (IAEG) on MDG Indicators. The indicators, like the targets adopted, were subject to periodic review and updating. ${ }^{36}$ Gender based indicators provided a distinct strand for reporting within the broader suite of MDGs indicators and this proved useful in drawing them out for public consumption. ${ }^{37}$

In addition to the MDG regime's own treatment of gender, the UNDP also observed that the law proved centrally important to progressing MDG 3, identifying it as providing a foundational '... national framework establishing the principles of gender equality' and as key in instituting practical steps to promote women's representation in legislative bodies. ${ }^{38}$ In sum however, the UNDP in reviewing this MDG, concluded that, although progress had been made, 'parity remains a distant goal'. ${ }^{39}$ That said, the effect of MDG 3 also needs to be considered in the context of the broader regime. Thus, it is significant that the UNDP, in charting progress on the MDGs across 34 countries, identified what it referred to as a 'catalytic' effect of action of gender equality on the other MDGs ${ }^{40}$ and pointed to the utility of the integration of gender with other issues. ${ }^{41}$

\section{Gender, the SDGs and the 2030 Agenda for Sustainable Development ${ }^{42}$}

\footnotetext{
${ }^{36}$ Millennium Development Goals Indicators https://mdgs.un.org/unsd/mdg/Host.aspx?Content=Indicators/About.htm> accessed 09 May 2017.

${ }^{37}$ See, for example, the eight page long, colourful and highly illustrated, 'Millennium Development Goals Gender Chart', 2015

<https://mdgs.un.org/unsd/mdg/Resources/Static/Products/Progress2015/Gender_Chart_Web.pdf> accessed 09 May 2017.

${ }^{38}$ UNDP Path, above n 31, 26-7.

${ }^{39}$ Ibid, 31.

${ }^{40}$ Ibid, 9-10.

41 Ibid, 31.

${ }^{42}$ Agenda 2030, above n 2.
} 
17 SDGs were agreed, a substantially increased 169 targets $^{43}$ set, and a colossal 232

indicators developed under the new regime, ${ }^{44}$ which is, beyond the basic goals, ponderous in comparison to its predecessor. The mushrooming of targets and indicators, while on the one hand speaks to expanded ambition, on the other gives pause to the viability of any claim they can offer to provide a clear steer to and simplifying the communication of the regime's progress.

The goals themselves despite the lengthy, sophisticated and open consultative process that produced them, were in the end, perhaps inevitably given the international law and policy context, the subject of a great deal of last minute horse-trading, ${ }^{45}$ which proved inimical to a fully reasoned outcome. That said, gender does retain the specific headline coverage in the SDGs that it enjoyed in the MDGs, specifically in Goal 5. The coverage offered here mixes top-down and bottom-up elements. ${ }^{46}$ Also in common with the preceding regime, a crosscutting approach, which (at least to a degree) recognises the challenges of intersectionality ${ }^{47}$ is adopted and gender issues appear under some (but not all) other goals in their associated targets which have significant gender dimensions and implications. In fact, women and/or gender are mentioned in some of the targets adopted under more than

\footnotetext{
${ }^{43}$ Millennium Development Goals Gender Chart 2015, above n 37, 31.

${ }^{44}$ Report of the Inter-Agency and Expert Group on Sustainable Development Goal Indicators (E/CN.3/2017/2), 16 September 2016 Annex III <https://unstats.un.org/unsd/statcom/48th-session/documents/2017-2-IAEGSDGs-E.pdf> accessed 09 May 2017.

${ }^{45}$ EGM/SDG Report of the Expert Group Meeting on the CSW 60 Priority Theme: Women's Empowerment and the link to Sustainable Development, 2015, (hereafter EGM/SDG Report) <http://www.unwomen.org//media/headquarters/attachments/sections/csw/60/csw60\%20egm\%20report.pdf?vs=1710> accessed 12 May 2017. See also Valeria Esquivel (2016) 'Power and the Sustainable Development Goals: a feminist analysis' (2016) Gender and Development 24(1) 9.

${ }^{46}$ EGM/SDG Report, ibid, 18.

${ }^{47}$ Defined as 'the multiple and intersecting identities (and thus exclusions) of gender, class, color, caste, creed, ability, age, sexuality, migratory status and geographic location.' Ibid, pp 6-7.
} 
half of the other SDGs. ${ }^{48}$ While there has undoubtedly been progress in this regard, there are a couple of remarkable gaps in coverage for gender in the targets set under SDG 14 (life below water) and SDG 15 (life on land) which cover areas related to reproductive activity (broadly understood as relating to human life support) such as food production, that have readily recognisable gender implications. Nonetheless, regardless of the pros and cons of each approach, on the whole coverage in targets for gender has developed significantly, as reflected in the fact that $25 \%$ of the targets across all 17 goals explicitly or implicitly address gender equality/women's empowerment. ${ }^{49}$

An enlightening and salient analysis of the substance of the SDG approach to gender ${ }^{50}$ emerged in the run-up to the sixtieth session of the Commission on the Status of Women (CSW) 60 in 2016, which focused on women's empowerment and sustainable development, evoking obvious opportunities to consider synergies and antipathies between the two areas of activity. The Expert Group Meeting report that fed into the CSW focussed attention on the SDGs as applied to the key areas of gender equality, women's empowerment and human rights and found them wanting in several key respects, specifically: finance; accountability; addressing power asymmetries; and data collection and monitoring. ${ }^{51}$ The question of language in respect of the gender/sustainable development nexus was raised as a particular cause of disquiet. ${ }^{52}$ As far as the SDGs are concerned, it seems that their

\footnotetext{
${ }^{48}$ Specifically 1 (poverty), 2 (hunger), 4 (education), 6 (clean water and sanitation), 8 (decent work and economic growth), 11 (sustainable cities and communities), 13 (climate action) and 17 (partnerships for the goals) <http://www.undp.org/content/undp/en/home/sustainable-development-goals.html> accessed 12 May 2017.

${ }^{49}$ EGM/SDG Report, above n 45, 18.

${ }^{50}$ Report of the Expert Group Meeting on the CSW 60 Priority Theme, Women's Empowerment and the link to Sustainable Development (2015), <http://www2.unwomen.org/ /media/headquarters/attachments/sections/csw/60/csw60\%20egm\%20report.pdf?v $=1 \& \mathrm{~d}=20160415 \mathrm{~T} 171710>$ accessed 29 July 2016 .

${ }^{51}$ Ibid, 3 .

52 Ibid.
} 
habitual approach, in cutting loose from the anchor of the legal lingua franca of human rights and replacing it with a random mix of political, technical, donor and civil society usage, generates obfuscation, inevitably begetting confusion and adding an unwelcome further layer of complexity to an already complicated endeavour. At this point and in light of what we will consider below, it is difficult to view this as anything other than a deliberate, ongoing choice, serving to effectively defuse claims pertaining to the legal enforceability of goals.

\section{The Pros and Cons of a Targets/Indicators-based Approach}

\section{Selection and Data Issues}

The approach adopted by the MDGs and perpetuated in the SDGs arguably illustrates both the strengths and weaknesses of a target-based, indicator-driven approach to attempting to induce societal change. Among the principal limitations of such an approach is the fact, referred to above, that this type of approach tends to promote concentration on identified target areas at the expense of others. ${ }^{53}$ Such an approach also tends to focus on targets that are easily reducible or translatable into quantitative terms. These do go some way towards generating change, but are likely to have limited impact in feeding the necessary qualitative culture change that is required to address the underlying causes of societal ills such as gender inequality. ${ }^{54}$ Nonetheless, an indicators/target-based approach, rather than being subject to interrogation and critique, has been significantly expanded upon and extended in relation to the SDGs generally, ${ }^{55}$ and to addressing gender issues specifically ${ }^{56}$ therein. The

\footnotetext{
${ }^{53}$ As acknowledged in the UN MDG Report 2015, above n 22, 31.

${ }^{54}$ V. Benschop and M. Verloo 'Sisyphus' Sisters: Can Gender Mainstreaming Escape the Genderedness of Organizations?' (2006) Journal of Gender Studies 15, 19.

55 UN MDG Report 2015, above n 22. 13.

${ }^{56}$ Largely reiterating the SDG approach: 'To achieve universal realization of gender equality and empowerment of women, it is critical to address the key areas of gender inequality, including gender-based discrimination in
} 
SDG regime then is essentially proceeding on the assumption that 'more of the same' will secure progress and will be adequate to tackle the problems that are evident in the established approach, but this seems unlikely to gain much traction in so-doing.

Selection of indicators is obviously a core concern, but more fundamentally the very malleability of the medium renders it open to cynical political manipulation. ${ }^{57}$ At heart this creates a real danger that the selected proxy or representation of progress isolated in an indicator or target comes to function as a surrogate or even a substitute for broader progress. That said, the UN review of the MDGs was not blind to such problems and it did also state, more ambitiously and suggesting the need to enculturate change that: 'Gender perspectives should be integrated fully into all goals of the post-2015 development agenda. ${ }^{58}$

Centring a regime on indicators raises other important issues. Not least of these is what may be referred to as the 'data dilemma'. While it is true to say that staggering developments in information and communications technology (ICT) ${ }^{59}$ have been instrumental to the development and functioning of MDG regime and will prove central to the SDGs, there is a danger that pre-occupation with their advances can lead to losing sight of their limitations. Data science has struggled to keep pace with the relatively modest demands of monitoring

law and in practice; violence against women and girls; women's and men's unequal opportunities in the labour market; the unequal division of unpaid care and domestic work; women's limited control over assets and property; and women's unequal participation in private and public decision-making.' Ibid, 31 .

${ }^{57}$ See, for example, G. MacNaughton and D. F. Frey,' Decent Work, Human Rights and the Sustainable Development Goals' (2016) Georgetown Journal of International Law 47, 607, pointing to an at best evasive and arguably at worst actively cynical treatment of decent work under the MDG and SDG regimes that ensures that they are insulated from established human rights-based protections.

${ }^{58}$ UN MDG Report 2015, above n 22, 13.

${ }^{59}$ Ibid at 10-13. 
the MDG targets/indicators set, with data disaggregation in particular, proving problematic with respect to gender throughout the duration of the MDGs. ${ }^{60}$ Other systemic problems include lack of quality control, ${ }^{61}$ patchy coverage, delay in release, and inequalities in access to the new technologies that now permeate this area of social endeavour. ${ }^{62}$ The more ambitious SDGs will inevitably place greater demands on data monitoring than was the case with the MDGs, and the UN itself is promoting no less than a 'data revolution' to facilitate the post-2015 agenda. ${ }^{63}$ The latter concept is open to various interpretations: '... some emphasise citizen accountability, others new forms of social and geophysical data, new ways of sharing data and many other facets. ${ }^{64}$ The differences between these are crucial but, as yet, under-interrogated.

Even if these foundational issues of principle are not addressed, advancing the status quo that emerged under the MDGs in less fundamental ways is possible. Espey, for example, recommended four key steps to improve on existing levels of data quality, specifically: first, agreeing a limited set of global SDG indicators; second, filling in gaps in the suite of indicators; third, improving the frequency of SDG data reporting (ideally moving to an annual obligation); and fourth, establishing a new Global Partnership for Sustainable

\footnotetext{
${ }^{60}$ UNDP Path, above n $31,30$.

${ }^{61}$ See A. Thurston, 'Can We Access and Trust Digital Records to Support Development Goals?' in Friends of Sustainable Governance (eds), Governance for Sustainable Development (New World Frontiers 2015) e-book <https://www.article19.org/data/files/medialibrary/38064/Full-Governance-Book.pdf> accessed 10 July 2017.

${ }^{62}$ See J. Espey, 'The Data Revolution for Sustainable Development' in Friends of Sustainable Governance (eds), Governance for Sustainable Development (New World Frontiers 2015) e-book <https://www.article19.org/data/files/medialibrary/38064/Full-Governance-Book.pdf> accessed 10 July 2017. ${ }^{63}$ See the Secretary-General's Independent Expert Advisory Group on a Data Revolution for Sustainable Development (IEAG): A World That Counts: Mobilising the Data Revolution for Sustainable Development online at <http://www.undatarevolution.org/report/> accessed 07 December 2016.

${ }^{64}$ Espey, above n 62.
} 
Development Data to offer leadership, foster innovation, mobilize additional resources and promulgate global standards for data harmonization and use. ${ }^{65}$

That more general access to the data/information underpins sustainable development is widely recognised, for example in the 2010 Lyon Declaration on Access to Information and Development, ${ }^{66}$ drafted under the auspices of the International Foundation of Library Associations and Institutions and enlisting the support of key information brokers in preparation for and support of the SDG regime. The Lyon Declaration is particularly interesting in identifying that the need to address gender issues in this regard is of central importance, particularly in Article 2 which states that: 'Sustainable development must take place in a human-rights based framework', addressing inequality through 'the empowerment, education and inclusion of marginalized groups, including women ...' ${ }^{67}$

Indicators based approaches clearly depend on sound data for their success or, as Thurston pithily puts it when discussing the SDGs: 'accountability benefits depend on the quality of information'. ${ }^{68}$ This is (as discussed above) problematic in itself and, on balance, observations such as those outlined strongly suggest that, without a sound supporting regime architecture, data-driven indicators approaches are not at the present time (and are perhaps not capable of being) sufficient to secure accountability in the pursuit of the SDGs. They certainly cannot bear the burden of primacy that the current regime places on them.

\footnotetext{
${ }^{65}$ Note that Espey recommended a maximum of regime 100 indicators - considerably fewer than those eventually adopted - supported by broader set of national indicators, ibid. This inevitably prompts questions as to the efficacy of the 232 regime indicators eventually endorsed.

66 The Lyon Declaration on Access to Information and Development <http://www.lyondeclaration.org/> accessed 13 December 2016.

${ }^{67}$ Ibid article 2(a).

68 Thurston, above n 61.
} 
In consequence of the above considerations, data defects and deficits raise several important issues, not least of which is the spectre of states 'playing the system' as the monitoring and verification of the data supplied is likely at least in some areas to be problematic, if not impossible. More fundamentally, as alluded to above, an indictors-based approach may also tempt states to prioritise actions which 'count' in terms of the SDG regime, to the detriment of broader coverage, including rights-based entitlements. Finally, however much supporting data science improves, the fact remains that quantitative indicators can never fully capture qualitative concerns, and that too heavy a reliance on them risks institutionalising a damaging reductionism. It is therefore no surprise that the UNDP's examination of the MDGs revealed that social and cultural attitudes have a major impact on progress (the same must apply to the lack thereof) towards goals in general, and that where gender is in play, this tendency is even more marked. ${ }^{69}$ Nothing in the determinedly indicators-based SDG regime is likely to address this.

\section{Indicators, Communication and Gender}

The prime appeal of indicators is that, on one level, they represent the siren call of clear communication - they can and do indicate direction of travel on headline activities - and (if well selected) they offer relative clarity and comparability. ${ }^{70}$ That said, while, indicators may communicate clearly, even if apt, they do so at the cost of the extreme simplification (with all the perils that entails as to their accuracy and efficacy) of oftentimes complex areas of

\footnotetext{
${ }^{69}$ UNDP Path, above n 31, 13.

70 W. Twining, 'Globalization and Comparative Law' (1999) Maastricht J European and Comparative Law 6(217), 240.
} 
societal endeavour. ${ }^{71}$ Selection is however centrally important for reasons of principle and not just practicality - from a gender perspective, for example, language, and target and indictor choices, are hugely significant, as they can, if ill-chosen, perpetuate and even reinforce victim status. ${ }^{72}$ Kapur points to the importance of emphasis in selective approaches to complex issues such as gender, noting that in the human rights sphere there is a danger that the prevailing emphasis on violence: 'reinforces gender and cultural essentialism in the human rights arena. ${ }^{73}$ The same criticism can be levelled at targets and indicators focussed on gender-based violence. ${ }^{74}$

For all their disadvantages, indicators-based approaches, well-deployed, can promote a degree of transparency and popularise areas of concern in the public domain. They can also allow specific issues and overlaps to be drawn out of the wider data-set highlighting particular areas of concern, as done to promising effect with gender in the MDG regime, ${ }^{75}$ and it is to be hoped this will continue to develop. The SDGs do offer an extended, ${ }^{76}$ and seemingly somewhat more transparent and nuanced selection ${ }^{77}$ of (9) $\operatorname{targets}^{78}$ and (14) indicators ${ }^{79}$ clustered around gender, than did the MDGs - though, as discussed above, they

\footnotetext{
${ }^{71}$ UNEP: Environmental Indicators for North America UNEP, Nairobi, 2006.

${ }^{72}$ R. Kapur, 'Tragedy of Victimization Rhetoric: Resurrecting the "Native” Subject in International/PostColonial Feminist Legal Politics' (2002) Harvard Human Rights Journal 51(1), 1.

73 Pardy, above n 10, 41.

${ }^{74}$ See Report of the Inter-Agency and Expert Group on Sustainable Development Goal Indicators, above n 45, for the prominence of this issue in the SDG approach and its inclusion as a goal under SDG 5.

75 See, for example, the Millennium Development Goals Gender Chart 2015, above n 37.

${ }^{76}$ Notable developments include the coverage offered to unpaid work.

${ }^{77}$ For coverage of discussion surrounding the selection of the indicator set, see. Goal 5 Achieve gender equality and empower all women and girls online at <https://unstats.un.org/sdgs/files/metadata-compilation/MetadataGoal-5.pdf> accessed 9 May 2017.

${ }^{78}$ Sustainable Development Knowledge Platform: Goal 5 <https://sustainabledevelopment.un.org/sdg5> accessed 9 May 2017.

${ }^{79} \mathrm{Ibid}$. Note that there are other indicators that touch on gender, here though the focus is only on Goal 5 as the main point of entry. Report of the Inter-Agency and Expert Group on Sustainable Development Goal Indicators, above $n$ 44, 7-8.
} 
necessarily remain constrained by their nature, form and content as quantitative, potentially manipulatable snapshots of qualitative societal progress.

The Elephant in the Room - Human Rights and Development Goals

On reflection, probably the most fundamental question relating to the development goals based approaches lies in the type of obligation they are viewed as producing. Further complexity is added to this question by the evolving nature of goals-based approaches. Specifically, while the MDGs process was arguably primed and pushed by the developed world, the SDGs have seen a more collaborative approach in partnership with the developing world in shaping coverage. ${ }^{80}$

In any case, states were in the MDGs and are in the SDGs willing to accept a goals-based approach as part of the political agenda, as means to revivify state ambition and augment the political prominence of state activity to address development/sustainability issues. However, the complex mix of sovereignty, resource distribution, broader democratic and specific legal obligations founded on human rights ${ }^{81}$ inevitably beg problematic questions as to what goals can and do involve. Tensions between the goals-based approach and human rights concerns are inevitably central among these in many respects, given that the subject matter of the goals brings the concerns, interests, and very often established and/or emerging legal rights of individuals, groups and communities into play.

\footnotetext{
${ }^{80}$ Discussed in MacNaughton and Frey, above n 57.

${ }^{81}$ B. Ruis, 'The Millennium Development Goals and the Rule of Law - Round Table Dialogue' (2005) Environmental Policy and Law 35(2), 84.
} 
While on the face of things, human rights and the development approaches share obvious common ground, the nexus between them has long been contentious at best. Thus the lost opportunity to develop a synergistic approach between them in the MDGs was a consequence not only of states effectively evading the issue, but also aided in part by the entrenched turf war between the human rights and development constituencies and a lack of vision concerning the opportunities that the MDGs offered them both. ${ }^{82}$ The disconnect that featured in the MDG regime, between the goals and established human rights regimes and its continuation in the projected SDGs, did however become a bone of contention through the negotiation of the latter. In marked distinction to what had been the case with the MDGs, the porous, multi-stakeholder approach to the negotiation of the SDGs ${ }^{83}$ saw the human rights constituency prove itself very much alive to the virtues of exploiting the potential of the development goals/human rights nexus. ${ }^{84}$ The unprecedented public consultation that foregrounded the development of the SDGs was also strongly flavoured by discussion of the connections between the goals and human rights. ${ }^{85}$ In light of these factors, it can be said that rights-talk permeated the negotiation process. ${ }^{86}$

\footnotetext{
${ }^{82}$ See, for example P. Alston, 'Ships Passing in the Night: The Current State of the Human Rights and Development Debate seen through the Lens of the Millennium Development Goals' (2005) Human Rights Quarterly 27(3), 755.

${ }^{83}$ See, passim MacNaughton and Frey, above n 57.

${ }^{84}$ Chairpersons of the UN Human Rights Treaty Bodies Joint Statement on the Post-2015 Development Agenda, May 2013, (Hereafter, CUNHRB Joint Statement)

<http://www.ohchr.org/_layouts/15/WopiFrame.aspx?sourcedoc=/Documents/HRBodies/TB/AnnualMeeting/Jo intStatementChairsMeetingMay2013.doc\&action=default\&DefaultItemOpen=1> accessed 02 May 2017. Civil society took a like tack, see. For example, Dhananjayan Sriskandarajah and Mandeep Tiwana, 'Hearing the neediest voices, community and public participation in development: Why civil society and civil space matter', Friends of Sustainable Governance (eds), Governance for Sustainable Development, New World Frontiers (2015) e-book <https://www.article19.org/data/files/medialibrary/38064/Full-Governance-Book.pdf> accessed 10 July 2017.

${ }^{85}$ MacNaughton and Frey, above n 57, 644.

${ }^{86}$ J. H. Knox, 'Human Rights, Environmental Protection, and the Sustainable Development Goals' (2015)

Washington. International Law Journal 24(517), 524.
} 
Key UN actors took the importance of the rights agenda on board in the SDG negotiating process. For example, the Secretary-General, called for the SDGs to act as a 'springboard' for 'a future free from poverty and built on human rights' $;{ }^{87}$ and the High-Level Panel of Eminent Persons on the Post-2015 Development Agenda, in like vein for them to be 'grounded in respect for universal human rights.' 88

The human rights constituency within the UN was also vocal in signposting the SDGs/human rights nexus. A joint statement of the Chairpersons of the UN Human Rights Treaty Bodies in 2010 clearly set out the early and fundamental concern that the goals even if achieved: '... would still fall short of what human rights treaties require, as treaties call for the realization of human rights for all, which goes beyond the reaching (sic) of quantified targets. ${ }^{89}$ The human rights bodies therefore posited the view that, in order to be 'sustainable' the development goals 'needed to be grounded in human rights, justice and the rule of law. ${ }^{90}$

In other UN processes, proponents of human rights saw the Rio+20 Outcome Document, 'The Future We Want' as hugely significant in signalling the international community's recognition of the links between the planned SDGs and human rights ${ }^{91}-$ and indeed the

\footnotetext{
${ }^{87}$ B. Ki Moon, 'A Life of Dignity for All: Accelerating Progress Towards the Millennium Development Goals and Advancing the United Nations Development Agenda Beyond 2015 - Report of the Secretary-General' UN Doc A/68/202 June 19, 2012, 18

<http://www.un.org/millenniumgoals/pdf/A\%20Life\%20of\%20Dignity\%20for\%20All.pdf> accessed 18 November 2016.

${ }^{88}$ Secretary-General, High Level Panel of Eminent Persons on the Post-2015 Development Agenda, A New Global Partnership: Eradicate Poverty and Transform Economies Through Sustainable Development, (Hereafter, SGHLPEP), 5 <http://www.post2015hlp.org/wp-content/uploads/2013/05/UN-Report.pdf> accessed 09 May 2017.

${ }^{89}$ CUNHRB Joint Statement, above n 84, 2.

${ }^{90}$ Ibid, 1 .

${ }^{91}$ Ibid, 2.
} 
document was peppered with supportive references to human rights. ${ }^{92}$ However, the soft status of the outcome document should perhaps have sounded a note of caution both in terms of its likely heft in setting the tone for the SDGs, and as indicative of state reluctance to accept further binding obligations on sustainability.

Civil society too was widely and strongly supportive of demands to integrate human rights into the development goals process. ${ }^{93}$ In a Joint Statement by 332 civil society organisations from across the globe, the aspiration for a human-rights grounded vision of the SDGs was expressed as signalling a shift from: '... a model of charity to one of justice, based on the inherent dignity of people as human rights-holders, [and] domestic governments as primary duty-bearers ...' ${ }^{94}$ Even if this ambition did not gain traction, the statement went on to indicate that the least that could be expected was that the SDGs would '... respect and reflect pre-existing human rights legal norms, standards and political commitments to which governments have already voluntarily agreed. ${ }^{95}$ However, all of this broad-based support availed little as the goals would ultimately have to be agreed by states and they had already, in the context of the MDGs, shown a tendency to evade associations with human rights and the legal claims that they would facilitate which could be used as additional means to hold them to account in regard to development goals.

\footnotetext{
${ }^{92}$ A/RES/66/288 The Future We Want <http://www.un.org/ga/search/view_doc.asp?symbol=A/RES/66/288\&Lang=E> accessed 26 April 2017. For example, reference was made to human rights in general in paras 8, 9, 58(d) and 145 and to gender equality in paras 8, 31, 146 and 240 .

${ }^{93}$ See, for example, the Joint Statement from 332 Civil Society Organizations, Human Rights for All Post-2015 (Dec. 10, 2013) <https://sustainabledevelopment.un.org/content/documents/5123joint.statement.dec10.pdf> accessed 12 May 2017 and the Vienna C+20 CSO Declaration (26 June 2013), para 57 <https://viennaplus20.files.wordpress.com/2013/04/vienna20-cso-declaration-final.pdf> accessed 09 May 2017. ${ }^{94}$ Joint Statement from 332 Civil Society Organizations, ibid, 1.

95 Ibid.
} 
The Women's Major Group (WMG) took an approach towards promoting the links between

the goals and human rights that was in harmony with that of civil society more generally.

The WMG, which comprised an impressive 500 plus civil society organisations ranging across human rights, environment and development, as well as academics and activists, ${ }^{96}$ was also particularly active in the SDG negotiating process, ${ }^{97}$ offering substantial input throughout. ${ }^{98}$ The WMG stressed gender equality and achieving women's human rights as key and constant framing principles in their engagement. ${ }^{99}$ The WMG found the negotiations open and inclusive, though not unproblematic. ${ }^{100}$ For example, while the WMG welcomed resistance of attempts to water down gender protection; the adoption of Goal $5 ;^{101}$ and the inclusion of gender in the targets set for other goals; ${ }^{102}$ on the whole, it viewed the process and its outcomes ${ }^{103}$ as lacking in ambition and disappointing. At a fundamental level, the SDGs in adopting: 'another set of reductive goals, targets and indicators that ignore the transformational changes required to address the failure of the current development model ...' (as gender activists had feared ${ }^{104}$ ) utterly missed the mark, failing to address the structural and power inequalities that underpin gender disadvantage. ${ }^{105}$ Centrally for

\footnotetext{
96 WMG: Women's "8 Red Flags," above n 17, 1.

${ }^{97}$ See Gabizon et al, above n 16.

${ }^{98}$ For example, Women's Major Group, Gender Equality, Women's Rights and Women's priorities:

Recommendations for the proposed Sustainable Development Goals (SDGs) and the Post 2015 Development Agenda, September 2013 <http://www.wecf.eu/download/2013/FinalReportfulldocument2013-09-

16_With_Covercopy.pdf> accessed 12 May 2017.

${ }^{99}$ Ibid, notably, E. Blomstrom with contributions from M. Ballara, 'The case for gender equality and rights in the SDGs' 59.

${ }^{100}$ See, for example, WMG: Women's “8 Red Flags,” above n 17, 1.

101 Ibid.

102 Ibid, 2.

${ }^{103}$ Women's Major Group, On Sustainable Development and Post 2015

<http://www.womenmajorgroup.org/category/policy-statements/on-sustainable-development-and-post-2015> accessed 15 May 2017.

${ }^{104}$ WMG 'Feminist Visions of Structural Transformations for Achieving Women's Human Rights and Gender Equality in the 2014 (sic) Development Agenda' Statement adopted 21 March 2103, at the Bonn Conference "Advancing the Post-2015 Sustainable Development Agenda" from 20-22 March 2013, reproduced ibid, 6-7. 105 A. I. Abelenda, 'A Feminist Perspective on the Post-2015 Development Agenda' (2014) The Equal Rights Review 13, 117 <http://www.equalrightstrust.org/ertdocumentbank/ERR\%2013\%20-\%20Abelenda.pdf> accessed 10 July 2017.
} 
present purposes, in identifying what it termed 'red flags' in the SDGs, the WMG took the

view that human rights issues had not been adequately addressed:

The SDGs do not fully aim to protect and fulfil human rights for all which should be at the centre of a socially just and ecologically sustainable development agenda as well as the means for achieving it. The recognition of Women's and Girls' human rights in the title of Goal 5 on gender equality, the human right to food, the right to water and sanitation as a goal, women's rights to decision making on peace and security, the rights of indigenous peoples, and the right for women to control their sexuality free of coercion, discrimination and violence ... amongst others are notably absent. ${ }^{106}$

In short, the SDGs as adopted, perpetuate the disingenuous decoupling of states' political obligations on development from human rights protections that was begun by the MDGs. Less tangibly, but just as problematic, is the fact that this approach also robs the development and human rights communities of valuable opportunities to exploit mutual reinforcement of their aims.

For gender issues, given the very direct and central rights based coverage already in place in international law alluded to above; the lack of integration, or less charitably, deliberate disarticulation of the SDGs from this milieu is particularly significant. The human rights agenda and the views of the chairpersons of the UN human rights treaty bodies are again particularly pertinent. In 2013, they pointed to the inadequacy of the coverage proposed for gender, observing that:

The goal of gender equality did not ensure the elimination of discrimination against women and equality between women and men, which should be addressed as a global priority in the future agenda ... ${ }^{107}$

\footnotetext{
106 WMG: Women's "8 Red Flags," above n 17, 2.

${ }^{107}$ CUNHRB Joint Statement, above n 84, 2.
} 
Despite wide-ranging expert advice ${ }^{108}$ dispensed in the negotiation of the SDGs on the need to articulate the nexus between them and human rights provision, the ultimately ambiguous $^{109}$ treatment of the nature of the interface of the SDGs with human rights law and rhetoric, represents a further deliberate choice by states to eschew an approach that would firmly moor the goals to an established legal anchor, with potential heft in terms of enforcement. Thus, the danger signalled by the Special Rapporteur on Human Rights and the Environment that the SDGs would continue down the path first taken by the MDGs of: '... trying to further some human rights goals without explicitly referring to them' is made manifest. $^{110}$

Similar concerns were also evident in civil society as indicated in the Post-2015 Human Rights Caucus Open letter on the SDGs ${ }^{111}$ and gender issues are prominent here, pointing to the imperative need for the goals to:

Comprehensively support the human rights of women and girls according to international standards and agreed commitments. The future framework should ensure that gender equality and women's rights are embedded throughout all goals, targets and indicators, that robust specific funding for women's rights is in place, and that the meaningful participation by women's rights groups, organizations and movements in implementation, monitoring and accountability mechanisms is guaranteed. ${ }^{112}$

SDG 5, the top layer of the nested system as adopted, is expressed thus: 'Achieve gender equality and empower all women and girls' ${ }^{113}$ pointedly not mentioning 'women's rights'. ${ }^{114}$

\footnotetext{
${ }^{108}$ See, for example, the SGHLPEP, above n 88, and the CUNHRB Joint Statement, above $\mathrm{n} 84$.

109 This was apparent in the negotiation process, see, for example, Knox, who criticised the language if the targets insufficiently concrete and not '... closely linked to existing human rights obligations ...' above n 86, 524.

110 Ibid, 526.

111 Post-2015 Human Rights Caucus Open letter on the SDGs, Sept 29, 2014

<http://www.civicus.org/images/HRs_Caucus_Letter_to_SG_-_29Sep2014.pdf> accessed 13 December 2013.

112 Ibid.

${ }^{113}$ SDGs Goal 5 <http://www.un.org/sustainabledevelopment/gender-equality/> accessed 9 May 2017.

${ }^{114}$ Gabizon et al, above n 16, 4.
} 
Specific mention of rights under SDG 5 is scant and largely relegated to the middle layer of the nested structure - targets ${ }^{115}$ - as is reference to eliminating discrimination. ${ }^{116}$ The only rights-based coverage appears in the lowest tier of the regime, indicators (incidentally proving that while indicators are not normally rights-based in current praxis, they are not conceptually incapable of being so) are 5.A.1 and $2 .{ }^{117}$ The choice of language is highly significant. ${ }^{118}$ What is at stake here is an arguable devaluation of gender issues by dissociating them from the recognised realm of human rights, diluting coverage by distancing or even divorcing gender from the established 'anti-discrimination' and 'equality' rights-based agendas coverage of which is relegated to inclusion in two of the nine targets under the goal and the indicators nested thereunder. Gender continues to be a live topic for discussion in the SDG regime, featuring prominently in the High Level Political Forum (HLPF) meeting in July 2017. The ensuing Ministerial Declaration is, for example, peppered with now familiar hortatory references to women/gender issues, among which States:

... underscore that all other Sustainable Development Goals need to be implemented in a manner that delivers results for women and girls. We urge that countries fully integrate gender equality strategies into national sustainable development frameworks so as to promote greater policy coherence, recognizing that achieving gender equality will require both targeted action as well as mainstreaming gender into all our efforts. ${ }^{119}$

\footnotetext{
${ }^{115}$ Specifically: 5.6 'reproductive rights'; and 5.A 'equal rights to economic resources, as well as access to ownership and control over land and other forms of property, financial services, inheritance and natural resources, in accordance with national laws' (the latter clause however effectively neuters this provision <https://sustainabledevelopment.un.org/sdg5> accessed 12 May 2017.

${ }^{116}$ Specifically: 5.1: 'End all forms of discrimination against all women and girls everywhere'. Ibid.

117 5.A.1: '(a) Proportion of total agricultural population with ownership or secure rights over agricultural land, by sex; and (b) share of women among owners or rights-bearers of agricultural land, by type of tenure' and 5.A.2: 'Proportion of countries where the legal framework (including customary law) guarantees women's equal rights to land ownership and/or control. Ibid.

118 Gabizon et al, above n 16,4 .

${ }^{119}$ E/2017/L.29-E/HLPF/2017/L.2, Ministerial declaration of the 2017 high-level political forum on sustainable development, convened under the auspices of the Economic and Social Council, on the theme "Eradicating poverty and promoting prosperity in a changing world" < http://www.un.org/ga/search/view_doc.asp?symbol=E/HLPF/2017/L.2\&Lang=E> accessed 31 July 2017, para 17.
} 
SDG 5 was subject to specifc review at the forum, and predictably, the link between human rights and gender emerged as an issue [back]grounding the debate, but again, in cohortative terms. ${ }^{120}$ If this is disappointing, it is hardly unexpected. There are however elements in the HLPF process that are more encouraging: not least in pointing to the need to take action on the 'gap' in the SDGs in dealing with structural aspects of gender equality; ${ }^{121}$ and in addressing data inadequacy. The latter point may ultimately prove highly significant in forging an indirect connection between the SDGs and human rights regimes, as raised in the HLPF background note on the review of SDG 5:

Human rights monitoring and documentation methodologies, which include qualitative indicators and context-specific analysis, are critical complementary tools to indicator selection and measurement to enable a fuller understanding of whether States are meeting their human rights obligations, towards women and girls. ${ }^{122}$

In the end though, states have not been convinced to volunteer change at a fundamental level that would directly and meaningfully engage human rights protection either in developing and, thus far, in progressing the SDGs and they cannot be compelled to do so. This is dispiriting not only in itself, but also because the SDGs regime as adopted and as it progresses makes it all too apparent that engagement in the debate by non-state actors on this front, at considerable cost in resources, time, effort, energy, and good will, has not in the end much changed the formal agenda. The failure to commit to human rights-based coverage in principle may however ultimately prove to be less of a barrier in practice, if the

\footnotetext{
${ }^{120}$ HLPF on Sustainable Development, Background Note on 2017 HLPF Thematic review of SDG 5: Achieve gender equality and empower all women and girls <https://sustainabledevelopment.un.org/content/documents/14383SDG5format-revOD.pdf> accessed 31 July 2017. This document makes one reference to CEDAW that is in many ways illustrative of the more general approach, highlighting 'opportunity' rather than obligation, that is adopted in the discussions, at 7.

${ }^{121} \mathrm{lbid}$, at 8-9.

122 Ibid at 9.
} 
approach to data discussed at the HLPF goes on to bear fruit. The fact that, as discussed above, there are significant problems with providing adequate data to fuel the SDG process, may mean that this provides fertile ground for such development.

Gender concerns, amongst others, will then continue to suffer the adverse consequences of a lack of acknowledgement of the connectivity between the SDGs and the machinery of international human rights law, as states continue to be reluctant to give cognizance to the fact that the goals are factually enmeshed with the latter. In the end, this intensifies the vulnerability of the SDGs to side-lining and tokenism by states and leads one to question how serious their intent is.

Hillary Clinton famously said that: '... the rights of women and girls is the unfinished business of the $21^{\text {st }}$ Century. ${ }^{123}$ While the SDGs do represent another step (albeit a comparatively limited one) along the road towards gender equality, they will not, as they presently stand, expressed as the gift of political targets rather than as the product of legal rights, suffice to take us to that much to be desired destination. Gender equality remains at best work in (oftentimes achingly slow) progress and, civil society engagement is integral to progressing it - as it is to the success of the SDGs. ${ }^{124}$ As things stand, there is however a very real danger that the inherent limitations of goals/targets/indicators and their failure to engage with rights-based approaches may well lead to questions as to the continuing salience of the former relative newcomers to the global polis. It may well also be the case that goals-based

\footnotetext{
${ }^{123}$ J. Fuller, 'Hillary Clinton Says Equality for Women is the 'Great Unfinished Business of the 21st Century' The Washington Post 7 March 2014 <https://www.washingtonpost.com/news/postpolitics/wp/2014/03/07/hillary-clinton-says-equality-for-women-is-the-great-unfinished-business-of-the-21stcentury/> accessed 08 August 2016.

${ }^{124}$ EGM/SDG CSW 60 Report, above n 45, 6.
} 
approaches, if they continue on the present trajectory, will come to be viewed as otiose by the human rights and gender constituencies, prompting them to disengage and shift focus to other areas where their efforts are more likely to avail. 